\title{
First Manic Attack During COVID-19 Treatment: A Case Report
}

\author{
Nalan Varsak', Mert Topaloğlư ${ }^{2}$, Elif Özdemir ${ }^{2}$ \\ Departments of ${ }^{1}$ Psychiatry and ${ }^{2}$ Emergency, Malazgirt State Hospital, Muş, Turkey
}

On March 11, 2020, the World Health Organization declared that the infection of novel coronavirus identified in Wuhan, China, is a pandemic. Various studies have shown that SARS-CoV-2 infection can trigger psychiatric effects such as anxiety, depression, and bipolar disorder. Here, we reported a case with no significant psychiatric history who experienced first-episode mania during the COVID-19 treatment. On the third day of hospitalization, the patient's mood was elevated, she thought she can treat other patients with her special power, she was talkative and irritable. Olanzapine $20 \mathrm{mg}$ was started and the patient's score on the Young Mania Rating Scale decreased on the 17th day. Psychiatric outcomes associated with covid 19 are just emerging and it seems likely to be a potential engagement for psychiatric professionals in the future. More studies are required in terms of the treatment, course, and follow-up of psychiatric sequelae in these patients.

KEY WORDS: COVID-19; Mania; Psychiatry.

\section{INTRODUCTION}

In December 2019, viral pneumonia of unknown cause are identified in Wuhan, China [1]. On March 11, 2020, the World Health Organization (WHO) declared that the infection of novel coronavirus is a pandemic [2]. Since then, coronavirus cases have increased worldwide. As of 21 October 2020, more than 40.7 million cases have been confirmed, with more than 1.12 million deaths from COVID-19 [3]. Although the respiratory system is the most affected system, experiments on these viruses have shown the ability to settle in and affecting the central nervous system (CNS). Many publications are showing that COVID-19 disease causes neuropsychiatric symptoms [4]. Bipolar disorder (BD) is a severe, chronic neuropsychiatric disorder that causes unusual shifts in mood, energy, activity levels, concentration, and the ability to carry out daily work [5]. Some studies have shown that $\mathrm{BD}$ has early and late age-of-onset (AAO), and some have

Received: December 7, 2020 / Revised: February 1, 2021

Accepted: February 2, 2021

Address for correspondence: Nalan Varsak

Department of Psychiatry, Malazgirt State Hospital, Saltuggazi

Mahhallesi Hastane Caddesi Malazgirt Devlet Hastanesi Psikyatri Klinigi, Malazgirt, 49400 Muş, Turkey

E-mail: nalanvarsak@gmail.com

ORCID: https://orcid.org/0000-0002-5866-5414 indicated that early, middle, and late AAO [6].

Here, we report a case of a female patient who experienced first-episode mania during the COVID-19 treatment. Written consent is obtained from the legal guardian.

\section{CASE}

On August 22, 2020, a 64-year-old woman with no significant psychiatric history was brought to our emergency department for agitation. She was under treatment for COVID-19 for 1 week at outer central. On August 15, 2020, the patient and her all family including her husband and 3 sons were admitted to the hospital with a chief complaint of fever and myalgia for 5 days and headache, diarrhea, taste, and smell disorder. Ten days ago before the symptoms had begun, their relatives had come from another city for condolence. A chest computed tomographic (CT) scan showed bilateral patchy shadows and groundglass opacity in the lung consistent with a COVID-19 pneumonitis. A nose and throat swab taken on admission for the presence of severe acute respiratory syndrome coronavirus 2 (SARS-CoV-2) viral RNA was negative despite other family members. Due to their contact history, symptoms, and CT scan consistent with COVID-19, our patient and her husband were hospitalized at an outer center. The

(c) This is an Open-Access article distributed under the terms of the Creative Commons Attribution Non-Commercial License (http://creativecommons.org/licenses/by-nc/4.0) which permits unrestricted non-commercial use, distribution, and reproduction in any medium, provided the original work is properly cited. 
patient received Hydroxychloroquine tablets, Enoxaparin sodium by subcutaneous, Salbutamol, and Methylprednisolone by inhaler for supportive care and symptomatic treatments.

On the third day of hospitalization, the patient's mood was cheerful and irritable, the other day she had started to sing hymns aloud and throw things out of the window. She had thought that she had a special power to treat other patients. She told her son that she had seen a religious leader and he had given her two prayer rugs so she had started to pray day and night. Her husband who was hospitalized in the same room had been disturbed by his wife because she was talkative and irritable. On the seventh day she had charged from the hospital, due to her agitation and hostile behaviors, the patient was brought to our emergency room (ER). Because of her quarantine process, she was examined at the isolation unit at ER. During the initial psychiatric consultation, the patient was disorganized and singing songs aloud. She was hostile to her son and had aggressive behaviors. Because of her aggressiveness like punching the door and yelling, $20 \mathrm{mg}$ haloperidol and $5 \mathrm{mg}$ biperiden was performed by intramuscular and in follow up because of her agitation going on, the same dose of haloperidol and biperiden was performed again. The initial ER workup was compatible with COVID-19 infection. To exclude neurologic situations the patient was consulted by the neurology department. A non-contrast CT scan of the brain and neurologic examination was obtained and was unremarkable. According to the anamnesis taken from the patient's relatives and psychiatric examination, a manic attack was considered as the diagnosis. The Young Mania Rating Scale (YMRS) was 43. Because she was unmanageable in the isolation unit, she was wanted to be referred to a local mental health service but could not find a place for hospitalization due to the density. So the patient was treated as outpatient and zuclopenthixol acetate and $10 \mathrm{mg}$ haloperidol was performed by intramuscular. Zuclopenthixol decanoate every 2 weeks and $2 \times 10 \mathrm{mg}$ olanzapine prescribed.

The patient's score of YMRS was decreasing when antipsychotics were added. Her YMRS score decreased from 43 to 9 on the 17 th day of the manic attack. Biperiden $2 \times$ $2 \mathrm{mg}$ added for her extrapyramidal side effects. Zuclopenthixol decanoate was stopped and $2 \times 10 \mathrm{mg}$ olanzapine was continued. On follow up olanzapine dose was gradually reduced to $10 \mathrm{mg}$.

\section{DISCUSSION}

In this case, we presented a patient who experienced first-episode mania during the COVID-19 treatment. According to our knowledge, there are a number of publications in the literature that show psychiatric symptoms due to COVID-19 disease. There are several reasons why COVID-19 might have psychiatric symptoms. One of these reasons is neurotropism and direct damage of SARS-CoV-2 infection of the CNS. SARS-CoV-2 has a protein on its surface that can bind to the human receptor angiotensin-converting enzyme 2 which is expressed mainly in the lungs and the gastrointestinal tract but little in the endothelial cells of the brain so it can enter CNS $[7,8]$.

The other reason is the inflammation can affect CNS by immune system activation. There is growing evidence that the inflammation might be associated with the pathogenesis of bipolar disorder [9]. Previous studies have reported increased production of proinflammatory cytokines such as interleukin (IL)-6, interleukin-8, and tumor necrosis factor (TNF)- $\alpha$ in bipolar patients [10-12]. It is known that SARS-CoV-2 infection can activate a cascade of inflammation too. A recent study has shown increased cytokine levels in COVID-19 patients compared to the control group [13] and in another study, it has been found that especially IL-6, IL-10, and TNF- $\alpha$ were increased in the severe SARS-CoV-2 cases [14]. As shown in these studies, the increased cytokine levels may have caused the onset of the manic episode seen in our patient.

Another reason is that stressful life events can trigger bipolar disorder as well as many psychiatric illnesses [15]. Stressful life events like loss of loved ones, job loss, interpersonal problems, childhood trauma, and any other traumas are important changes that can influence personal and social situations [16]. Since the emergence of the COVID-19 pandemic, we have faced many stress factors such as ongoing uncertainty about when and how will the pandemic end, the number of cases still increasing, lack of definitive treatment, social isolation, quarantine, fear of illness and death, loss of loved ones, unemployment, economic uncertainty $[17,18]$.

Recently, it has been reported that a patient who experienced her first manic attack during quarantine due to contact while she was negative for SARS-CoV-2 [19]. In a review that compiles studies investigating the psychological consequences of COVID-19, it is recommended 
health systems be prepared to respond to the potential increase in requirement for mental health services [20].

Although the relationship of the manic episode of the patient with COVID-19 is not certain, the absence of previous psychiatric history and the first attack during the treatment of COVID-19 led us to present this case. More studies are required in terms of the treatment, course, and follow-up of psychiatric sequelae in these patients.

\section{Conflicts of Interest}

No potential conflict of interest relevant to this article was reported.

\section{Author Contributions}

Conceptualization: Nalan Varsak, Mert Topaloğlu, Elif Özdemir. Data acquisition: Nalan Varsak, Mert Topaloğlu. Writing-original draft: Nalan Varsak. Writing - review and editing: Nalan Varsak.

\section{ORCID}

Nalan Varsak https://orcid.org/0000-0002-5866-5414

Mert Topaloğlu https://orcid.org/0000-0003-4892-7406

Elif Özdemir https://orcid.org/0000-0003-4086-3911

\section{REFERENCES}

1. World Health Organization. Rolling updates on coronavirus disease (COVID-19) [Internet]. Geneva: World Health Organization [cited at 2020 Apr 9]. Available from: https://www. who.int/emergencies/diseases/nove/-coronavirus-2019/ events-as-they-happen.

2. Montalvan V, Lee J, Bueso T, De Toledo J, Rivas K. Neurological manifestations of COVID-19 and other coronavirus infections: a systematic review. Clin Neurol Neurosurg 2020;194:105921.

3. Coronavirus disease (COVID-19) situation dashboard. ArcGIS. COVID-19 dashboard by the Center for Systems Science and Engineering (CSSE). Johns Hopkins University; 2020.

4. Rogers JP, Chesney E, Oliver D, Pollak TA, McGuire P, FusarPoli $\mathrm{P}$, et al. Psychiatric and neuropsychiatric presentations associated with severe coronavirus infections: a systematic review and meta-analysis with comparison to the COVID-19 pandemic. Lancet Psychiatry 2020;7:611-627.

5. Muneer A. Staging models in bipolar disorder: a systematic review of the literature. Clin Psychopharmacol Neurosci 2016; 14:117-130.
6. Bolton S, Warner J, Harriss E, Geddes J, Saunders KEA. Bipolar disorder: trimodal age-at-onset distribution. Bipolar Disord 2020. doi: 10.1111/bdi.13016. [Epub ahead of print]

7. Walls AC, Park YJ, Tortorici MA, Wall A, McGuire AT, Veesler D. Structure, function, and antigenicity of the SARS-CoV-2 spike glycoprotein. Cell 2020;181:281-292.e6.

8. Baig AM, Khaleeq A, Ali U, Syeda H. Evidence of the COVID-19 virus targeting the CNS: tissue distribution, host-virus interaction, and proposed neurotropic mechanisms. ACS Chem Neurosci 2020;11:995-998.

9. Rosenblat JD, McIntyre RS. Bipolar disorder and inflammation. Psychiatr Clin North Am 2016;39:125-137.

10. O'Brien SM, Scully P, Scott LV, Dinan TG. Cytokine profiles in bipolar affective disorder: focus on acutely ill patients. J Affect Disord 2006;90:263-267.

11. Brietzke E, Mansur RB, Soczynska JK, Kapczinski F, Bressan RA, McIntyre RS. Towards a multifactorial approach for prediction of bipolar disorder in at risk populations. J Affect Disord 2012;140:82-91.

12. Himmerich $\mathrm{H}$, Patsalos $\mathrm{O}$, Lichtblau $\mathrm{N}$, Ibrahim MAA, Dalton B. Cytokine research in depression: principles, challenges, and open questions. Front Psychiatry 2019;10:30.

13. Han H, Ma Q, Li C, Liu R, Zhao L, Wang W, et al. Profiling serum cytokines in COVID-19 patients reveals IL-6 and IL-10 are disease severity predictors. Emerg Microbes Infect 2020; 9:1123-1130

14. Chen G, Wu D, Guo W, Cao Y, Huang D, Wang H, et al. Clinical and immunological features of severe and moderate coronavirus disease 2019. J Clin Invest 2020;130:2620-2629.

15. Umeoka EHL, van Leeuwen JMC, Vinkers $\mathrm{CH}$, Joëls $\mathrm{M}$. The role of stress in bipolar disorder. Curr Top Behav Neurosci 2020. doi: 10.1007/7854_2020_151. [Epub ahead of print]

16. Aldinger F, Schulze TG. Environmental factors, life events, and trauma in the course of bipolar disorder. Psychiatry Clin Neurosci 2017;71:6-17.

17. Torales J, O'Higgins M, Castaldelli-Maia JM, Ventriglio A. The outbreak of COVID-19 coronavirus and its impact on global mental health. Int I Soc Psychiatry 2020;66:317-320.

18. Archard D, Caplan A. Is it wrong to prioritise younger patients with COVID-19? BMJ 2020;369:m1509.

19. Yin X, Sun Y, Zhu C, Zhu B, Gou D, Tan Z. An acute manic episode during 2019-nCoV quarantine. J Affect Disord 2020; 276:623-625.

20. Arora T, Grey I, Östlundh L, Lam KBH, Omar OM, Arnone D. The prevalence of psychological consequences of COVID-19: a systematic review and meta-analysis of observational studies. J Health Psychol 2020. doi: 10.1177/1359105320966639. [Epub ahead of print] 